\title{
Effects of donor plant age and explants on in vitro culture of Cedrela montana Moritz ex Turcz
}

\author{
Sofía Basto ${ }^{1 凶}$, Carlos Serrano ${ }^{2}$, Elizabeth Hodson de Jaramillo ${ }^{3}$
}

Received: 19-06-2012 Accepted: 07-11-2012 Published on line: 28-11-2012

Edited by Alberto Acosta

\begin{abstract}
To evaluate the organogenic potential of Cedrela montana Moritz ex Turcz, explants from mature (10-20 year-old) and juvenile (7-18 month-old) trees were collected. The first grouping included buds, leaves, and nodes derived from juvenile basal offshoots and rejuvenated shoots from cuttings. The second, included leaves, petioles, nodes, internodes and nodes of in vitro elongated shoots. The highest organogenic potential was observed in nodes from juvenile trees: $45.8 \%$ of explants presented axillary bud elongation, while $56.2 \%$ presented rooting in a growth regulator free culture medium. Fiftyone percent of elongated shoots produced adventitious shoots with $0.5 \mu \mathrm{M}$ NAA and $0.5 \mu \mathrm{M} \mathrm{BA} ; 30 \%$ with $0.5 \mu \mathrm{M}$ NAA and $1 \mu \mathrm{M} \mathrm{BA}$; and $30 \%$ with $1 \mu \mathrm{M}$ BA. Twenty percent presented roots with $0.5 \mu \mathrm{M}$ NAA. Root formation was stimulated in a medium supplemented with activated charcoal $\left(5 \mathrm{gL}^{-1}\right)$. The acclimatization of eighty percent of plantlets regenerated from nodes, and of $72.5 \%$ in vitro generated shoots was successful. On the contrary, mature trees material presented low organogenic response. Axillary bud elongation was recorded just in $10.7 \%$ of explants from juvenile shoots and in $6.7 \%$ of explants from rejuvenated shoots. In conclusion the age of donor plant and type of explant affect the organogenic potential of $C$. montana. This study contributes to the understanding of this species' response under in vitro conditions.
\end{abstract}

Key words: Cedrela montana, Meliaceae, tropical forestry, woody plant tissue culture, in vitro, vegetative propagation.

1 Unidad de Biotecnología Vegetal, Departamento de Biología, Facultad de Ciencias, Pontificia Universidad Javeriana, Bogotá, D.C., Colombia.

2 Consultor Independiente. Bogotá, D.C., Colombia.

3 Profesora Emérita, Facultad de Ciencias, Pontificia Universidad Javeriana. Bogotá, D.C., Colombia.
Efecto de la edad del material parental y del tipo de explante en el cultivo in vitro de Cedrela montana Moritz ex Turcz. Resumen. Para evaluar el potencial organogénico de Cedrela montana Moritz ex Turcz, se colectaron explantes de árboles maduros (1020 años) y juveniles (7-18 meses). Los primeros incluyeron yemas, hojas y nudos de brotes juveniles (ubicados hacia la parte basal del tronco) y rejuvenecidos (obtenidos a partir de estacas). Los segundos hojas, peciolos, nudos, entrenudos y nudos de brotes elongados in vitro. Los nudos de árboles juveniles presentaron el mayor potencial organogénico, ya que el 45,8\% de los explantes presentaron elongación de yemas axilares y el 56,2\% enraizamiento en medio sin reguladores de crecimiento. El 51\% de los brotes elongados formaron brotes adventicios con $0.5 \mu \mathrm{M}$ NAA y $0.5 \mu \mathrm{M}$ BA, el $30 \%$ con $0.5 \mu \mathrm{M}$ NAA y $1 \mu \mathrm{M}$ BA, y el $30 \%$ con $1 \mu \mathrm{M}$ BA; y el $20 \%$ raíces con $0,5 \mu \mathrm{M}$ NAA. La formación de raíces se vio estimulada con la adición de carbón activado $\left(5 \mathrm{gL}^{-1}\right)$ en el medio. El $80 \%$ de las plántulas regeneradas a partir de nudos y el $72,5 \%$ de las provenientes de brotes generados in vitro se aclimataron exitosamente. Por el contrario, explantes de árboles maduros presentaron baja respuesta organogénica. Elongación de yemas axilares fue registrada solamente en $10.7 \%$ de los nudos de brotes juveniles y en $6.7 \%$ de aquellos provenientes de brotes rejuvenecidos. En conclusión, la edad de la planta donadora y el tipo de explante influyen sobre el potencial organogénico de $C$. montana. Este estudio contribuyó al conocimiento de la respuesta de esta especie bajo condiciones in vitro.

Resumo. Para avaliar o potencial organogênico da Cedrela montana Moritz ex Turcz, explantes derivados de árvores adultas (10-20 anos) e jovens (7-18 meses) foram coletados. O primeiro incluiu brotos, folhas, e nós derivados de brotações jovens (localizado na direção da parte basal do tronco) e rejuvenescida (obtido a partir de estacas). O segundo incluía folhas, pecíolos, nós, entrenós e nós de brotos alongados in vitro. Maior potencial organogênico foi observado em nós de árvores jovens, em que o alongamento de brotos foi obtido em $45,8 \%$ dos explantes e o enraizamento atingiu 56,2\% em meio sem reguladores de crescimento. Brotos adventícios foram induzidas em $51 \%$ dos rebentos gerados in vitro com $0.5 \mu \mathrm{M}$ NAA e $0.5 \mu \mathrm{M} \mathrm{BA}$; $30 \%$ de indução ocorreu com $0.5 \mu \mathrm{M}$ NAA e $1 \mu \mathrm{M}$ BA; $30 \%$ com 1 $\mu \mathrm{M}$ BA. Raízes adventícias foram induzidas em $20 \%$ dos rebentos com $0,5 \mu \mathrm{M}$ NAA. Formação de raízes foi estimulada com carvão ativado $\left(5 \mathrm{gL}^{-1}\right)$ no meio. $80 \%$ das plântulas regeneradas a partir de nós e $72,5 \%$ das plântulas a partir de brotações obtidas in vitro foram aclimatizadas com sucesso. Em contraste, explantes derivados de árvores adultas apresentou resposta organogênica baixo. Alongamento de brotos de gemas axilares foi registrado somente em 10,7\% dos nós de brotações jovens e 6,7\% das brotações ejuvenescidas. Em conclusão a idade da planta doadora e o tipo de explante afeta o potencial de organogênese in vitro da C. montana. Este estudo contribuiu para o conhecimento da resposta desta espécie sob condições in vitro. 


\section{Introduction}

The Meliaceae is among the foremost tree families native to the Northern South America, an area rich in tree species essential to the wood manufacturing industry and biologically valuable to the region. Cedrela montana Moritz ex Turcz. belongs to this family; it is about $25-30 \mathrm{~m}$. tall, with thick greyish branches and pink wood (1). The tree is found in temperate and cool tropical climates, at 1,200-3,000 m. above sea level (2), and it is commonly used in the production of fine furniture (1). Similarly to other forest species often used in wood manufacturing, natural stands of C. montana have been subject to considerable genetic erosion by uncontrolled exploitation and habitat transformation. The 'cedro rosado' as it is known locally (2) is biologically valuable for soil protection and preservation of native animal populations (1).

Despite its broad variation in germination, between $40-90 \%$ (2), the propagation of C. montana is always by seed. However, micropropagation of selected phenotypes of C. montana is desirable since propagation by seed yields high levels of genetic variability, a limiting factor for its commercial use. Studies focused on in vitro propagation have achieved embryogenic callus induction from zygotic embryos (3). Other Cedrela species have also been micropropagated. For example, $C$. odorata has been propagated in vitro using shoot tips (4), seedling material (5-9), 2-wk-old hypocotyl segments (10) and nodal explants from juvenile cuttings from juvenile shoots from 10-12 year-old trees (11). C. tonduzii has been micropropagated from 6 month-old material (12), and C. fissilis by using nodal segments from seedlings produced from seeds under sterile conditions (13). In vitro propagation offers an alternative method not only to establish plantations with elite traits, but also to provide plant material for forest biodiversity conservation programs (14). The characteristics for selection of individuals can be identified in juvenile or, preferably, adult trees. This research explored the in vitro propagation of $C$. montana from juvenile and adult plant sources. As such, this study contributes to the understanding of the response of this species under in vitro conditions; it also sheds light on how to use this knowledge to improve applications on micropropagation and the conservation of $C$. montana.

\section{Materials and methods}

Tree material: Explants were excised from mature 10-20 year-old trees located in Subachoque, Cundinamarca, Colombia, and from juvenile 7-18 month-old plants at nurseries belonging to the CAR (Cundinamarca Regional Autonomous Corporation). Trees and juvenile plants were chosen based on their good phytosanitary conditions, height, and stem straightness. At a later stage, elongated in vitro shoots from nodes from juvenile material were used as an additional source of explants (Table 1). Rejuvenation methods were applied to adult material, these techniques included 1) obtaining offshoots formed spontaneously on the basal part of approximately 10 year-old trees, used as juvenilelike explant sources; and 2) rooting of cuttings to produce new shoots.

Table 1. Source of explants for in vitro culture of Cedrela montana.

\begin{tabular}{ll}
\hline $\begin{array}{l}\text { Mature 10-20 } \\
\text { year-old trees }\end{array}$ & $\begin{array}{l}\text { Juvenile 7-18 } \\
\text { month-old trees }\end{array}$ \\
\hline Buds & Leaves \\
Leaves & Petioles \\
$\begin{array}{l}\text { Nodes from juvenile } \\
\text { shoots of rooted and } \\
\text { unrooted cuttings }\end{array}$ & Nodes \\
$\begin{array}{l}\text { Nodes from basal } \\
\text { offshoots }\end{array}$ & $\begin{array}{l}\text { Internodes in vitro shoots } \\
\text { Elongated in juvenile material }\end{array}$ \\
\hline
\end{tabular}

Disinfection: In order to initiate aseptic cultures, 65 disinfection treatments were evaluated, using preliminary and concluding immersions in an antioxidant solution of citric acid $\left(2.5 \mathrm{~g} \mathrm{l}^{-1}\right)$ and ascorbic acid $\left(2.5 \mathrm{gl}^{-1}\right)$ for all disinfection treatments. Sodium hypochloride was used alone or with Tween 80 at concentrations between $0.75 \%$ and $2.5 \%$, and 
at different exposure times between 3 and $25 \mathrm{~min}$. Solutions of Benlate ${ }^{\circledR}$ and Orthocide ${ }^{\circledR}$, both at 0.05 , $0.1,0.2$ and $0.3 \%$, were used for $15,20,30$ or 60 min. An additional fungicide, Merteck ${ }^{\circledR}$, with active ingredient of Tiabendazol at $43.59 \% \mathrm{w} / \mathrm{w}$, was used at a concentration of $0.7 \mathrm{ml} \mathrm{l}^{-1}$ for $30 \mathrm{~min}$. Lastly, all explants were rinsed three times in sterile distilled water. Claforan ${ }^{\circledR}$, an antibiotic with active ingredient Cefotaxime, was added at a concentration of 250 $\mathrm{mg} / \mathrm{ml}$ to the basal media in different disinfection treatments. Disinfection treatments were used according to the type of explant.

Antioxidant treatments: The effect of antioxidants in the prevention of enzymatic browning of adult and juvenile explants was compared. Treatments included citric acid $\left(2.5 \mathrm{~g} \mathrm{l}^{-1}\right)$ and ascorbic acid (2.5 $\left.\mathrm{g}^{-1}\right)$, which were added individually or combined to sodium hypochloride, Benlate ${ }^{\circledR}$ and Orthocide ${ }^{\circledR}$ solutions, during the last rinsing in sterile distilled water, and to the culture media. Activated charcoal (AC) to $5 \mathrm{~g} \mathrm{l}^{-1}$ and polyvinylpyrrolidone (PVP) to $3 \mathrm{~g}^{-1}$ were included in culture media in different combinations.

In vitro culture: Growth was compared using the following media: Murashige \& Skoog (MS) (15), Schenk \& Hildebrandt (SH) (16), and Woody Plant Medium (WPM) (17). All basal media were tested in full concentration as well as with their macronutrients diluted to one-third. The $\mathrm{pH}$ was adjusted to 5.85 . Cultures were incubated at $26 \pm 2{ }^{\circ} \mathrm{C}$ under a $16 \mathrm{~h}$. photoperiod and light intensity of $65-135 \mu \mathrm{mol} \mathrm{m}{ }^{-2}$ $\mathrm{s}^{-1}$ provided by cool-white fluorescent tubes.

In order to promote organogenic response, nodes, petioles, internodes and leaf explants were treated with $\alpha$-Naphthaleneacetic acid (NAA) at 1.5, 5 and $15 \mu \mathrm{M}$, and benzyladenine (BA) at 4.4, 13.3 and $22.2 \mu \mathrm{M}$. Leaf explants were also treated with $\mathrm{BA}$ at $4.4,13.3$ and $22.2 \mu \mathrm{M}$, and kinetin $(\mathrm{KN})$ at 2.3, 4.6 and $23.2 \mu \mathrm{M}$. At a later stage, thidiazuron (TDZ) was also tested in the following concentrations: $2 \times 10^{-4}, 5 \times 10^{-4}, 1 \times 10^{-3}, 7 \times 10^{-3}, 0.01,0.03$, and 0.05 $\mu \mathrm{M}$. Further organogenic treatments applied to elongated shoots from nodes of juvenile material were based on combinations of BA $(0.5$ and $1 \mu \mathrm{M})$ and NAA $(0.5 \mu \mathrm{M})$, cultivated in darkness to induce rooting (14) during the first 15 days of culture. $\mathrm{MS} / 3 \mathrm{M}$ media was used in plant growth regulator experiments.

The material was transferred onto fresh media every 30 days. However, nodes from juvenile and rejuvenated shoots were transferred every 4 or 20 days, in order to avoid browning. Nodes from juvenile material were maintained during 120 days in the same media (solid MS/3M prepared with $8 \mathrm{~g}$ $1^{-1}$ Sigma ${ }^{\circledR}$ agar).

Acclimatization: The rooted plantlets derived from nodes of juvenile sources and those from in vitro-produced shoots were rinsed and freed of agar, then transferred to a 1:1 soil and charcoal substrate for 90 days. For 4 weeks, plantlets were covered with plastic wrap and irrigated every 3 days with water, in order to maintain a high relative humidity, and kept at $26 \pm 2{ }^{\circ} \mathrm{C}$ under $16 \mathrm{~h}$. photoperiod. Three days after transfer, and during the following 4 weeks, 1 $\mathrm{mm}$. diameter holes were punched into the plastic covers to promote gradual acclimatization. Plantlets were then transferred to the field.

Experimental design, data collection and statistical analysis: Experiments were carried out using a completely randomized design. Each experimental unit consisted of a glass flask $(4 \mathrm{~cm}$. diameter, $7 \mathrm{~cm}$. height, $125 \mathrm{ml}$. volume, covered with aluminium foil) containing one explant and 20 , $25,30,40$ or 100 repetitions per treatment, based upon availability of each type of plant material in the field. Following in vitro culture, and during 4 weeks, data were recorded on the percentage of explants with adventitious shoots and roots, the percentage of explants with callus, the number of shoots and roots per explant, the shoot and root length, and the percentage of explants with contamination and with browning. Data was analyzed by using the Chisquare $\left(X^{2}\right)$ tests with contingency tables. $p>0.05$ was considered significant.

\section{Results}

Adult material: Adult material presented low organogenic response. Explants directly excised from adult trees presented high browning levels; however, no significant differences were found at $\mathrm{p}>0.05$ (Chisquare test) between treatments with antioxidants in preventing browning of adult explants. Adult 
material was difficult to surface sterilize, particularly nodes from rooted and unrooted cuttings and buds ( $80 \%$ and $95 \%$ contamination, respectively). Leaves presented the lowest contamination among evaluated materials. Conversely to the differences between brown preventing treatments, a significant difference at $\mathrm{p}>0.05$ (Chi-square test) was found in desinfestation treatment of adult-derived leaves with $2 \%$ sodium hypochloride $10 \mathrm{~min}$., plus 30 min. immersion in a solution of $0.1 \%$ Benlate $^{\circledR}$ and $0.1 \%$ Orthocide $^{\circledR}(55 \%$ contamination), still, no organogenic response was observed (Table 1).

Nodes from juvenile shoots of rooted and unrooted cuttings presented high levels of contamination. The best surface disinfestation (20\% of explants) was obtained with a $2.5 \%$ sodium hypochloride treatment for 5 min. ( $p>0.05$ ) Chisquare test. The other rejuvenated source of explants, the basal offshoots, provided less numbers of suitable shoots for in vitro studies than rooted and unrooted cuttings. Significant differences were found at $\mathrm{p}>0.05$ (Chi-square test) between disinfestation treatments for basal offshoots. The best surface disinfestation was achieved with a $2 \%$ sodium hypochloride treatment for $25 \mathrm{~min}$., followed by rinsing in a Benlate ${ }^{\circledR}(0.1 \%)$ and Orthocide ${ }^{\circledR}$ $(0.1 \%)$ solution for $60 \mathrm{~min}$. This treatment presented just 13.3\% contamination; however, it yielded $92.2 \%$ browning $(p>0.05)$ Chi-square test. Shoot elongation from axillary buds from nodes of rejuvenated shoots of cuttings was observed in just $6.7 \%$ of explants (Table 2); however, shoot elongation was not observed despite transfer to medium with BA $(1.3 \mu \mathrm{M})$, and was followed by browning. Spontaneous shoot elongation from preexisting axillary buds from nodes of juvenile basal offshoots was observed in $10.7 \%$ of explants after 30-50 days (Table 2).

Juvenile material: Leaves from juvenile material, as well as those from adult trees, presented the lowest contamination among juvenile explants. No contamination was recorded by using an immersion in $1 \%$ sodium hypochloride for $15 \mathrm{~min}(\mathrm{p}>0.05)$ Chi-square test. No organogenic response was recorded. On the contrary, petioles developed callus in $3.9 \%$ of cases with $13.3 \mu \mathrm{M}$ BA and $5 \mu \mathrm{M}$ NAA, and internodes in $22 \%$ of cases with $22.2 \mu \mathrm{M}$ $\mathrm{BA}$ and $15 \mu \mathrm{M}$ NAA (non-significant Chi-square at p >0.05) (Table 2). Petioles and internodes were best disinfected with $2 \%$ sodium hypochloride treatment for $10 \mathrm{~min}$., followed by rinsing in a solution of Benlate $^{\circledR}(0.1 \%)$ and Orthocide ${ }^{\circledR}$ $(0.1 \%)$ for $60 \mathrm{~min}(\mathrm{p}>0.05)$ Chi-square test. This material presented $1.25 \%$ and $25 \%$ contamination respectively.

Nodes from juvenile trees showed the highest organogenic potential. With this material, AC treatment was beneficial in preventing browning at $\mathrm{p}>0.05$ (Chi-square test), only $12.5 \%$ of nodes browned when AC was added to the media. This antioxidant also aided organogenesis, making it possible to obtain adventitious roots in 18.8\% of the explants, the highest rooting percentage (non-significant Chi-square at $\mathrm{p}>0.05$ ). The best disinfection treatment for nodes was immersion in $0.75 \%$ sodium hypochloride solution for 15 min., and $30 \mathrm{~min}$. immersion in a solution of $0.1 \%$ Benlate $^{\circledR}$ and $0.1 \%$ Orthocide ${ }^{\circledR}$ ( $\left.\mathrm{p}>0.05\right)$ Chi-square test, this treatment yielded $20.8 \%$ contamination and $27.2 \%$ browning. Axillary buds of nodes cultured in medium devoid of growth regulators developed vigorous shoots in $45.8 \%$ of cases. Also, nodes presented $56.2 \%$ spontaneous rooting (Figure 1). Rooted plants survived hardening in $80 \%$ of cases. BA and NAA (4.422.2 and $1.5-15 \mu \mathrm{M}$, respectively) only stimulated the formation of callus in $5.8-42.8 \%$ of node

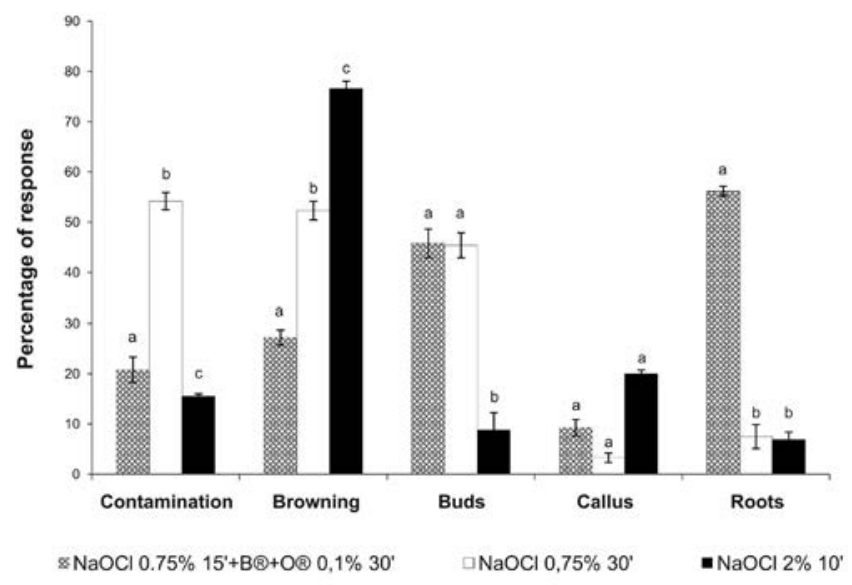

Fig. 1. Effect of disinfection treatments on the establishment of aseptic cultures of nodes from juvenile material of Cedrela montana, after 60 days of culture on MS/3M medium. Letters indicate significant differences at $\mathrm{p}>0.05$ (Chi-square test); bars indicate mean $\pm \mathrm{SE}$. 
Table 2. Cedrela montana donor-plant age and explant response to organogenic treatments.

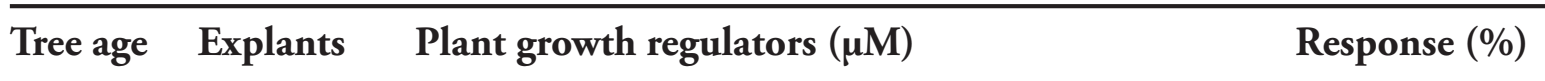

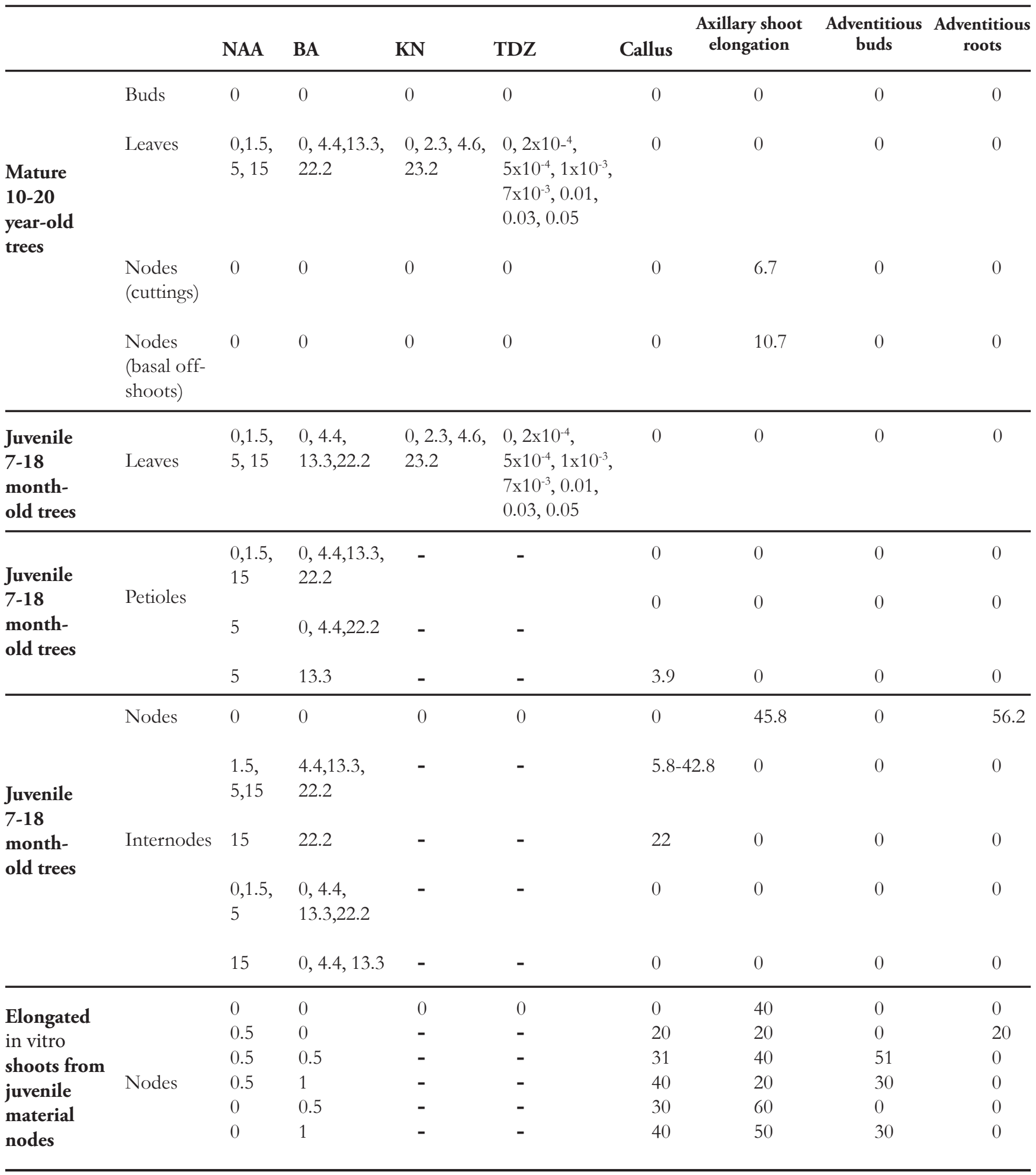

explants (non-significant Chi-square at $\mathrm{p}>0.05$ ) (Table 2). Moreover, nodes showed malformations (thickening) and abnormal development of shoots from existing buds.
Adventitious buds were induced in 51\% of in vitro-generated shoots with $0.5 \mu \mathrm{M}$ NAA and $0.5 \mu \mathrm{M} \mathrm{BA} ; 30 \%$ induction took place with 0.5 $\mu \mathrm{M}$ NAA, and $1 \mu \mathrm{M} \mathrm{BA}$; and $30 \%$ with $1 \mu \mathrm{M}$ BA 
alone (Figure 2). Adventitious roots were induced in $20 \%$ of in vitro-generated shoots with $0.5 \mu \mathrm{M}$ NAA alone (Figure 2). $72.5 \%$ of rooted plantlets survived hardening transfer to a (1:1) soil-tocharcoal substrate mixture. Shoot elongation from pre-existing axillary buds was observed in all organogenic treatments (Table 2).

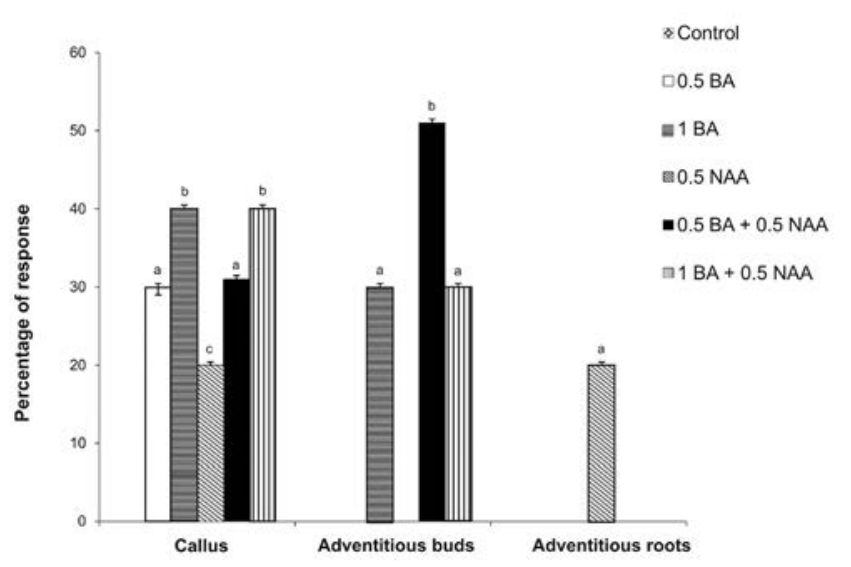

Fig. 2. Effect of treatments with BA and NAA, alone or combined, on organogenic response of explants from in vitro-produced shoots, derived from juvenile trees of Cedrela montana, after 30 days of culture. Letters indicate significant differences at $\mathrm{p}<0.05$ (Chi-square test); bars indicate mean $\pm \mathrm{SE}$.

Culture basal media: Both explants from adult and juvenile sources presented the best growth in $\mathrm{MS} / 3 \mathrm{M}$ medium. For adult material, shoot

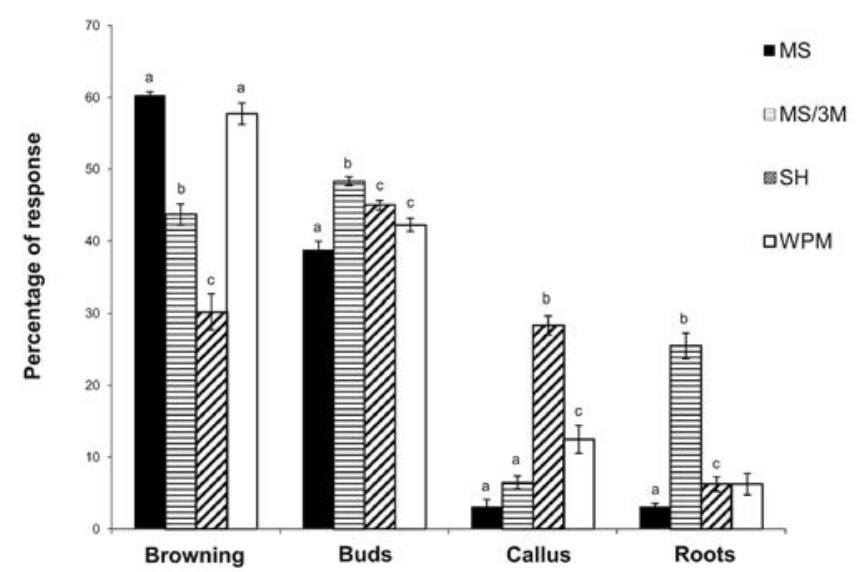

Fig. 3. Effect of culture media on browning and organogenic response of nodes from juvenile trees of Cedrela montana, after 60 days of culture. Letters indicate significant differences at $\mathrm{p}<0.05$ (Chi-square test); bars indicate mean $\pm \mathrm{SE}$. elongation from axillary buds was observed in 5.4\% of explants; adventitious roots were not observed. For juvenile material, shoot elongation from axillary buds was observed in $48.4 \%$ of explants and adventitious roots were observed in $25.5 \%$ of explants (Figure 3).

\section{Discussion}

The organogenic potential of mature plant material is lower than that of the juvenile origin material, which has also been recorded for another Cedrela species (10). Clonal propagation of mature $C$. montana trees was not achieved using these tissue culture techniques, most likely due to recalcitrance of mature explants, which could be examined by using other mature trees reinvigoration techniques (18). Mature explants lose morphogenetic potential due to tissue specialization, which reduces plasticity and cell differentiation capacity (19). This may be explained by the fact that at a mature stage, genes are expressed in different quantities of proteins with respect to those of juvenile tissues (20). There is also evidence that cytokinins decrease during tree maturation (21), thus reducing cell division and bud induction, and hastening aging of plant tissues. Another problem to the establishment of in vitro explants derived from adult trees in several species is the high percentage of contamination (22), particularly when the material is derived from natural populations, as was the case for C. montana. The highest contamination was recorded in nodes from rooted and unrooted cuttings and buds. A frequent problem in micropropagation of forest species when using adult material is explant browning produced while trying to control contamination (23).

Leaves from adult material showed no organogenic response even when NAA, BA, KN and TDZ were added to the media. TDZ is a highly effective regulator of in vitro morphogenesis and can induce differentiation and dedifferentiation in woody species (24), and contributes to rejuvenation of adult material among various forest species by inducing adventitious bud on organs such as leaves and internodes (25).

The most successful rejuvenated material evaluated in this study proved to be basal offshoots. 
This material, containing buds near the basal stem zone of the tree, has been recommended as source of rejuvenated explants because basal portions of trees retain juvenile characteristics for long periods of time (26). Rejuvenation of several forest species increases the amount of auxins in terminal buds, and increases cytokinin levels and reduces abscisic acid in axillary buds (21), consequently promoting plant growth and development. However, a young adult tree develops only 10-15 offshoots on its entire trunk making basal offshoots scarce. Scarcity of in vitro established basal shoot material continued to be remained a limitation for further organogenic evaluations. Vidal et al. (27) found that these epicormic shoots were more suitable for in vitro establishment and had greater capacity to develop shoots, callus and roots than top branch explants, seeing as top branches are older than epicormic branches, and explants taken from juvenile parts of mature trees presented juvenile characteristics. This is important in woody species, which have low regeneration capacities, given that some stem segments may have better nutrient translocation, and explant position along the stem of the donor plant is a determinant for responsiveness (18). Because of their return to a juvenile and more totipotent stage, C. montana rejuvenated explants exhibited a higher response than adult material.

Leaves were the only juvenile explant that showed no organogenic response, and the use of growth regulators and TDZ did not promote organogenesis in adult material. In Toona ciliate (another Meliaceae species) when using TDZ, Daquinta et al. (28) recorded callus and shoot formation on young leaf rachis explants. C. montana callus developed in internode and petiole explants from juvenile trees may provide material useful for embryogenesis or indirect organogenesis, this has been successfully achieved in other forest species (25).

Shoot elongation from pre-existing axillary buds from nodes was achieved using a growth regulator free culture medium. The fact that their use only stimulated the formation of callus suggests that exogenous and endogenous concentrations could have an inhibitory interactive effect (14) on explants under conditions tested here. Axillary buds proved a useful explant source for in vitro propagation of $C$. montana due to their high quality (vigour and phytosanitary state) and ease of manipulation. It was possible in the same medium to develop adventitious roots from nodes; therefore, endogenous concentrations of growth regulators seem appropriate. These results coincide with Da Costa et al. (13), who reported rooting rates of over $87 \%$ of C. fissilis node cuttings without growth regulators, and with Millán-Orozco et al. (29) regarding $C$. odorata shoots from seeds germinated in vitro. In addition to the continuous development of shoots and roots, nodes cultured in media without growth regulators remained viable for more than 16 weeks; as a result, this material can be regarded as potentially useful for future establishment of germplasm collections.

Elongated shoots from nodes cultured without growth regulators were excised for micropropagation and direct organogenesis. Similar procedures in other species and this rejuvenation method have provided enough material to allow massive propagation (30). Adventitious buds were induced in in vitro-produced shoots. Bud and root formation is the organogenic response that provides the potential for mass-propagation systems, where each explant can produce vast numbers of adventitious buds, each able to generate a plant if rooted. The induction of adventitious buds and roots can be expected since juvenile material is more responsive to growth regulators than older tissues, which has been confirmed in other studies (27).

Both development of shoots and roots from juvenile material and growth of adult material were better on MS/3M medium, most likely because modifying the basal composition of media can assist recalcitrance in woody plant species; in particular, macronutrients may affect cellular dedifferentiation (18).

The evaluation of C. montana under in vitro conditions contributed to identify the kind of explants, media and culture conditions with the highest optimization potential for developing a micropropagation and conservation system for this species. The results of this study provide openings to further develop research in explant response to other plant regulators not tested here. For example, Santamaria et al. (3) recorded a positive effect of brassinolide on $C$. montana in vitro germination, this can be used to promote organogenesis of this species. Other studies can focus on achieving somatic embryogenesis by using adult or juvenile leaves, the 
explant that presented the lowest contamination, or by testing floral organs.

\section{Conclusion}

The results indicate that the organogenic potential of C. montana depends upon donor plant age (adult or juvenile) and type of explant. Best results in this study were obtained with explant material derived from juvenile plants. Both nodes of adult and juvenile origin showed the highest organogenic potential, particularly those from juvenile trees. The organogenic response of mature C. montana explants evidenced that the massive propagation of selected adult phenotypes (elite trees) is unattainable by using the micropropagation protocols tested in this study. However, the basic procedures provided here for the future establishment of an in vitro propagation pathway with juvenile material can be a useful tool to large-scale reforestation programs. These results also provide guidelines to establish in vitro germplasm collections by using nodes from juvenile material and to establish a micropropagation system applicable to other forest species.

\section{Acknowledgements}

To Sandra Constantino for her feedback on previous versions of this manuscript, and the anonymous reviewers for their valuable comments.

\section{Financial support}

This work was supported by Grant No. 1203-07-00992 of Instituto Colombiano para el Desarrollo de la Ciencia y la Tecnología "Francisco José de Caldas" COLCIENCIAS.

\section{Conflicts of interests}

Authors declare that there are no conflicts of interest related to the results obtained in this study.

\section{References}

1. Parent G. Guía de reforestación. Primera edición. Corporación de la Meseta de Bucaramanga
(CDMB) - Agencia Canadiense para el Desarrollo Internacional (ACDI). Bucaramanga, Colombia. 1989. 123 p.

2. Bartholomaus A, De La Rosa A, Santos JO, Acero LE, Moosbrugger W. El manto de la tierra-flora de los Andes-guia de 150 especies de la flora andina. Primera edición. Corporación Autónoma Regional de las Cuencas de los Ríos Bogotá, Ubaté y Suárez (CAR), Deutsche Gesellschaft fur Technische Zusammenarbeit (GTZ) and Kreditanstalt fur Wiederaufbau (KfW). Bogotá, D.C., Colombia. $1990.332 \mathrm{p}$.

3. Santamaria JAL, Páez T, Soria N, Reyes C. Establecimiento de un protocolo para la germinación in vitro e inducción a callo embriogénico de cedro (Cedrela montana) a partir de embriones zigóticos. Biotecnología/Sangolquil ESPE 2012; http://repositorio.espe.edu.ec/ handle/21000/5505. Retrieved on: $23^{\text {rd }}$ September 2012.

4. Maruyama E, Ishii K, Saito A, Migita K. Micropropagation of cedro (Cedrela odorata L.) by shoot-tip culture. Journal of the Japanese Forestry Society 1989; 71 (8): 329-331.

5. Maruyama E, Ishii K, Saito A, Migita K. Screening of suitable sterilization of explants and proper media for tissue culture of eleven tree species of Peru-Amazon forest. Journal of Agricultural Science 1989; 33 (4): 252-261.

6. Valverde-Cerdas L, Dufour M, Villalobos V. In vitro organogenesis in Albizia guachapele, Cedrela odorata and Swietenia macrophylla (Fabaceae, Meliaceae). Revista de Biología Tropical 1998; 46 (2): 225-228.

7. Pérez J, Mesén F, Hilje L, Aguilar ME. Desarrollo de un método de micropropagación aplicable a genotipos selectos de Cedrela odorata L. Optimización de la fase de multiplicación. Revista Forestal Centroamericana 2002; 38, 67-71.

8. Rodríguez R, Daquinta M, Capote I, Pina D, Lezcano Y, González-Olmedo JL. Nuevos aportes a la micropropagación de Swietenia macrophylla $\mathrm{x}$ Swietenia mahogani (Caoba híbrida) y Cedrela odorata (Cedro). Cultivos Tropicales 2003; 224 (3): 23-27.

9. Valverde-Cerdas L, Rojas-Vargas A, Hine-Gómez A. In vitro propagation of Albizia guachapele, Cedrela odorata, Platymiscium pinnatum and Guaiacum sanctum. Plant Tissue Culture and Biotechnology 2008; 18 (2): 151-156.

10. Peña-Ramírez Y, Juárez-Gómez J, Gómez-López L, Jerónimo-Pérez J, García-Sheseña I, GonzálezRodríguez J, Robert M. Multiple adventitious shoot formation in Spanish Red Cedar (Cedrela odorata L.) cultured in vitro using juvenile and mature tissues: an improved micropropagation protocol for a highly valuable tropical tree species. In Vitro Cellular \& Developmental Biology - Plant 2010; 46 (2): 149-160. 
11. García-Gonzáles R, Delgado M, González Y, González A, Garriga M, Caligari PDS, Carrasco B, Quiroz K. In vitro propagation of cedar (Cedrela odorata L.) from juvenile shoots. Chilean Journal of Agricultural Research 2011; 71 (3): 376-382.

12. Guevara E, Hidalgo N, Murillo O. Cultivo in vitro de cedro dulce (Cedrela tondurii). Tecnología en Marcha 1992; 11 (3): 10-16.

13. Da Costa E, Volkmer CV, Netto F, Viana AM. In vitro culture of Cedrela fissilis Vellozo (Meliaceae). Plant Cell, Tissue and Organ Culture 2002; 70 (3): 259-268.

14. Pijut PM, Beasley RR, Lawson SS, Palla KJ, Stevens $\mathrm{ME}$, Wang Y. In vitro propagation of tropical hardwood tree species - A review (2001-2011). Propagation of Ornamental Plants 2012; 12 (1): 25-51.

15. Murashige T, Skoog F. A revised medium for rapid growth and bio assays with tobacco tissue cultures. Physiologia Plantarum 1962; 15 (3): 473-497.

16. Schenk RU, Hildebrandt AC. Medium and techniques for induction and growth of monocotyledonous and dicotyledonous plant cell cultures. Canadian Journal of Botany 1972; 50 (1): 199-204.

17. Lloyd G, McCown B. Commercially-feasible micropropagation of mountain laurel, Kalmia latifolia, by use of shoot-tip culture. Proceedings of the International Plant Propagators Society 1981; 30, 421-427.

18. Benson EE. Special symposium: In vitro plant recalcitrance: An introduction. In Vitro Cellular \& Developmental Biology-Plant 2000; 36 (3): 141-148.

19. Abdullah AA, Yeoman MM, Grace J. Micropropagation of mature Calabrian pine (Pinus brutia Ten.) from fascicular buds. Tree Physiology 1987; 3 (2): 123-136.

20. Garcia JL, Avidan N, Troncoso A, Sarmiento R, Lavee S. Possible juvenile-related proteins in olive tree tissues. Scientia Horticulturae 2000; 85 (4): 271 284.

21. Valdés AE, Fernández B, Centeno ML. Alterations in endogenous levels of cytokinins following grafting of Pinus radiata support ratio of cytokinins as an index of ageing and vigour. Journal of Plant Physiology 2003; 160 (11): 1407-1410.
22. Seth R, Kendurkar S, Nadgauda R. In vitro clonal propagation of Casuarina equisetifolia Forst. from mature tree-derived explants. Current Science 2007; 92 (3): 287-290.

23. Pandey S, Singh M, Jaiswal U, Jaiswal VS. Shoot initiation and multiplication from a mature tree of Terminalia arjuna Roxb. In Vitro Cellular \& Developmental Biology-Plant 2006; 42 (5): 389-393.

24. Duurkovič J. Rapid micropropagation of mature wild cherry. Biologia Plantarum 2006; 50 (4): 733-736.

25. Lall S, Mandegaran Z, Roberts AV. Shoot multiplication and adventitious regeneration in Sorbus aucuparia. Plant Cell, Tissue and Organ Culture 2006; 85 (1): 23-29.

26. Beck SL, Dunlop R, Van Staden J. Rejuvenation and micropropagation of adult Acacia mearnsii using coppice material. Plant Growth Regulation 1998; 26 (3): 149-153.

27. Vidal N, Arellano G, San-José MC, Vieitez AM, Ballester A. Developmental stages during the rooting of in-vitro-cultured Quercus robur shoots from material of juvenile and mature origin. Tree Physiology 2003; 23 (18): 1247-1254.

28. Daquinta M, Lezcano Y, Cid M, Pina D, Rodríguez R. Morfogénesis in vitro de Toona ciliata a partir de raquis de hojas jóvenes con tidiazuron. Revista Colombiana de Biotecnología 2005; 7 (2): 5-9.

29. Millán-Orozco L, Corredoira E, San José MC. In vitro rhizogenesis: histoanatomy of Cedrela odorata (Meliaceae) microcuttings. Revista de Biología Tropical 2011; 59 (1): 447-453.

30. Corchete MP, Diez JJ, Valle T. Micropropagation of Ulmus pumila L. from mature trees. Plant Cell Reports 1993; 12 (9): 534-536. 